\title{
Nitrate in Greenland and Antarctic ice cores: a detailed description of post-depositional processes
}

\author{
Regine RÖTHLiSberGer, ${ }^{1,2}$ Manuel A. HUtTerli, ${ }^{3}$ Eric W. WOLFF, ${ }^{2}$ Robert MULVANEY, ${ }^{2}$ \\ Hubertus Fischer, ${ }^{4}$ Matthias BIGLER, ${ }^{1}$ Kumiko GOTO-AZUMA,${ }^{5}$ Margareta E. HANSSON, \\ Urs RUTH ${ }^{4,7}$ Marie-Louise SIGGAARD-ANDERSEN, ${ }^{8}$ Jørgen P. STEFFENSEN ${ }^{8}$ \\ ${ }^{1}$ Climate and Environmental Physics, University of Bern, Sidlerstrasse 5, CH-3012 Bern, Switzerland \\ ${ }^{2}$ British Antarctic Survey, Natural Environment Research Council, Madingley Road, Cambridge CB3 OET, England \\ E-mail:rro@bas.ac.uk \\ ${ }^{3}$ Department of Hydrology and Water Resources, University of Arizona, Tucson, AZ 85721-0011, U.S.A. \\ ${ }^{4}$ Alfred Wegener Institute for Polar and Marine Research, P.O. Box 120161, D-27515 Bremerhaven, Germany \\ ${ }^{5}$ National Institute of Polar Research, 9-10, Kaga 1-chome, Itabashi-ku, Tokyo 173-8515, Japan \\ ${ }^{6}$ Department of Physical Geography and Quaternary Geology, Stockholms Universitet, S-106 91 Stockholm, Sweden \\ ${ }^{7}$ Institut für Umweltphysik, Universität Heidelberg, Im Neuenheimer Feld 299, D-69120 Heidelberg, Germany \\ ${ }^{8}$ Department of Geophysics, The Niels Bohr Institute for Astronomy, Physics and Geophysics, University of Copenhagen, \\ Juliane Maries Vej 30, DK-2100 Copenhagen, Denmark
}

\begin{abstract}
A compilation of nitrate $\left(\mathrm{NO}_{3}{ }^{-}\right)$data from Greenland has shown that recent $\mathrm{NO}_{3}{ }^{-}$concentrations reveal a temperature dependence similar to that seen in Antarctica. Except for sites with very low accumulation rates, lower temperatures tend to lead to higher $\mathrm{NO}_{3}{ }^{-}$concentrations preserved in the ice. Accumulation rate, which is closely linked to temperature, might influence the concentrations preserved in snow as well, but its effect cannot be separated from the temperature imprint. Processes involved in $\mathrm{NO}_{3}{ }^{-}$deposition are discussed and shown to be temperature- and/or accumulation-ratedependent. Apart from scavenging of nitric acid $\left(\mathrm{HNO}_{3}\right)$ during formation of precipitation, uptake of $\mathrm{HNO}_{3}$ onto the ice crystal's surface during and after precipitation seems to contribute further to the $\mathrm{NO}_{3}{ }^{-}$concentrations found in surface snow. Post-depositional loss of $\mathrm{NO}_{3}{ }^{-}$from the top snow layers is caused by release of $\mathrm{HNO}_{3}$ and by photolysis of $\mathrm{NO}_{3}{ }^{-}$. It is suggested that photolysis accounts for considerable losses at sites with very low accumulation rates. Depending on the site characteristic, and given that the temperature and accumulation-rate dependence is quantified, it should be possible to infer changes in atmospheric $\mathrm{HNO}_{3}$ concentrations.
\end{abstract}

\section{INTRODUGTION}

The nitrate $\left(\mathrm{NO}_{3}{ }^{-}\right)$record in polar ice cores is expected to contain information about past atmospheric concentrations of nitrogen oxides $\left(\mathrm{NO}_{x}=\mathrm{NO}+\mathrm{NO}_{2}\right)$ due to the close link between $\mathrm{NO}_{3}{ }^{-}$and $\mathrm{NO}_{x}$. The increase in atmospheric $\mathrm{NO}_{x}$ concentrations in the Northern Hemisphere caused by rising fossil-fuel combustion since approximately 1940, for example, is reflected in higher $\mathrm{NO}_{3}{ }^{-}$concentrations in Greenland snow (Neftel and others, 1985). However, past studies have shown that factors other than atmospheric $\mathrm{NO}_{x}$ concentrations also influence $\mathrm{NO}_{3}{ }^{-}$records (Wolff, 1995). In Greenland as well as in Antarctica, reversible deposition of $\mathrm{NO}_{3}{ }^{-}$and net losses in the top snow layers have been observed. It has been suggested that either re-evaporation of nitric acid $\left(\mathrm{HNO}_{3}\right)$ (Dibb and others, 1998; Mulvaney and others, 1998; Röthlisberger and others, 2000a) or photolysis of $\mathrm{NO}_{3}{ }^{-}$in the top few centimetres of the snowpack (Honrath and others, 2000; Jones and others, 2000) causes such post-depositional alterations.

In earlier studies, relationships between $\mathrm{NO}_{3}{ }^{-}$and accumulation rate have been proposed (Herron, 1982; Legrand and Kirchner, 1990; Yang and others, 1995), with generally higher accumulation rates associated with lower $\mathrm{NO}_{3}{ }^{-}$concentrations and higher $\mathrm{NO}_{3}{ }^{-}$depositional fluxes. In a more recent study based on a macroscopic deposition model, Fischer and others (1998) found a second-order polynomial dependence of average firn concentration and inverse snow accumulation.

Based on a compilation of $\mathrm{NO}_{3}{ }^{-}$data from more than 50 Antarctic sites covering various temperature and accumulation regimes, it has recently been suggested that temperature is also a key parameter in defining $\mathrm{NO}_{3}{ }^{-}$concentrations in Antarctic snow and ice, with lower temperatures leading to higher $\mathrm{NO}_{3}{ }^{-}$concentrations preserved in the snow (Röthlisberger and others, 2000a). Elevation has also been linked to $\mathrm{NO}_{3}{ }^{-}$concentrations, for both Greenland and Antarctica (Mulvaney and Wolff, 1994; Yang and others, 1996), but no statistically significant relationship has been found in a more recent study (Kreutz and Mayewski, 1999). The inherent connection between temperature, accumulation rate and elevation makes it difficult to distinguish between the separate effects, and no firm conclusions about their relative importance have yet been reached.

Here, we provide a detailed description of the processes involved in $\mathrm{NO}_{3}{ }^{-}$re-emission and a discussion of how temperature and accumulation rate affect those processes. In analogy to the compilation of $\mathrm{NO}_{3}{ }^{-}$data from Antarctic 
Table 1. Temperature, accumulation rate and $\mathrm{NO}_{3}{ }_{3}$ concentration for Greenland locations used in this study

\begin{tabular}{|c|c|c|c|c|c|c|c|c|}
\hline \multirow[t]{3}{*}{ Site (source) } & \multirow[t]{3}{*}{ Location } & \multirow{3}{*}{$\begin{array}{l}\text { Altitude } \\
\qquad \mathrm{m}\end{array}$} & \multirow{3}{*}{$\begin{array}{c}\text { Temperature } \\
{ }^{\circ} \mathrm{C}\end{array}$} & \multirow{3}{*}{$\begin{array}{l}\text { Accumulation } \\
\mathrm{g} \mathrm{cm}^{-2} \mathrm{a}^{-1}\end{array}$} & \multirow{2}{*}{\multicolumn{2}{|c|}{$\begin{array}{l}\mathrm{NO}_{3}^{-} \text {pre-1940 } \\
\text { Concentration Number of years }\end{array}$}} & \multicolumn{2}{|l|}{$\mathrm{NO}_{3}^{-}$post -1970} \\
\hline & & & & & & & Concentration & Number of years \\
\hline & & & & & $\mathrm{ppb}$ & & $\mathrm{ppb}$ & \\
\hline $1988-8^{1}$ & $64.6^{\circ} \mathrm{N}, 43.7^{\circ} \mathrm{W}$ & 2550 & -19.9 & 57 & & & 94 & 2 \\
\hline $1988-7^{1}$ & $64.8^{\circ} \mathrm{N}, 44.1^{\circ} \mathrm{W}$ & 2745 & -22.0 & 38 & & & 90 & 3 \\
\hline Dye $318 C^{2}, 20 D^{3}$ & $65.0^{\circ} \mathrm{N}, 44.9^{\circ} \mathrm{W}$ & 2617 & -22.3 & 41 & 53,55 & $174^{\mathrm{a}}, 30^{\mathrm{c}}$ & $100,122,132$ & $15,5,15$ \\
\hline Dye $3^{2,4}$ & $65.2^{\circ} \mathrm{N}, 43.8^{\circ} \mathrm{W}$ & 2491 & -20.0 & 49 & $44,52,52$ & $10^{\mathrm{b}}, 11^{\mathrm{b}}, 220^{\mathrm{h}}$ & $86,114,137$ & $6,7,2$ \\
\hline $1988-4^{1}$ & $66.6^{\circ} \mathrm{N}, 45.5^{\circ} \mathrm{W}$ & 2130 & -18.6 & 30 & & & 117 & 2 \\
\hline $1988-5^{1}$ & $67.0^{\circ} \mathrm{N}, 44.5^{\circ} \mathrm{W}$ & 2250 & -20.3 & 33 & & & 115 & 4 \\
\hline $1988-6^{1}$ & $67.2^{\circ} \mathrm{N}, 43.8^{\circ} \mathrm{W}$ & 2450 & -21.6 & 36 & & & 108 & 6 \\
\hline EGIG T $05^{5}$ & $69.9^{\circ} \mathrm{N}, 47.3^{\circ} \mathrm{W}$ & 1910 & -18.0 & 46 & & & 118 & 5 \\
\hline EGIG T09 $9^{5}$ & $70.0^{\circ} \mathrm{N}, 46.3^{\circ} \mathrm{W}$ & 2170 & -20.0 & 41 & & & 134 & 9 \\
\hline EGIG T13 $3^{5}$ & $70.2^{\circ} \mathrm{N}, 45.0^{\circ} \mathrm{W}$ & 2380 & -22.6 & 46 & & & 107 & 8 \\
\hline Milcent $^{2}$ & $70.3^{\circ} \mathrm{N}, 44.6^{\circ} \mathrm{W}$ & 2410 & -22.0 & 49 & 61 & $7^{\mathrm{g}}$ & & \\
\hline EGIG Tl $^{5}$ & $70.4^{\circ} \mathrm{N}, 44.1^{\circ} \mathrm{W}$ & 2530 & -23.8 & 44 & & & 117 & 9 \\
\hline EGIG T21 ${ }^{5}$ & $70.6^{\circ} \mathrm{N}, 43.0^{\circ} \mathrm{W}$ & 2700 & -24.8 & 44 & & & 112 & 9 \\
\hline Site $A^{2,6}$ & $70.6^{\circ} \mathrm{N}, 35.8^{\circ} \mathrm{W}$ & 3092 & -29.4 & 29 & $45,64,70$ & $3^{\mathrm{d}}, 2^{\mathrm{c}}, 19^{\mathrm{b}}$ & & \\
\hline Site $D^{6}$ & $70.6^{\circ} \mathrm{N}, 39.6^{\circ} \mathrm{W}$ & 3018 & -28.3 & 34 & 73 & $19^{\mathrm{b}}$ & & \\
\hline EGIG T $27^{5}$ & $70.8^{\circ} \mathrm{N}, 41.6^{\circ} \mathrm{W}$ & 2870 & -26.6 & 39 & & & 113 & 9 \\
\hline EGIG T $31^{5}$ & $70.9^{\circ} \mathrm{N}, 40.6^{\circ} \mathrm{W}$ & 2970 & -27.5 & 34 & & & 133 & 10 \\
\hline EGIG T $41^{5}$ & $71.1^{\circ} \mathrm{N}, 37.9^{\circ} \mathrm{W}$ & 3150 & -29.5 & 25 & & & 144 & 12 \\
\hline Crête $^{2}$ & $71.1^{\circ} \mathrm{N}, 37.3^{\circ} \mathrm{W}$ & 3172 & -30.0 & 28 & 60,80 & $60^{\mathrm{e}}, 2^{\mathrm{g}}$ & & \\
\hline EGIG T $43^{5}$ & $71.1^{\circ} \mathrm{N}, 37.3^{\circ} \mathrm{W}$ & 3172 & -30.1 & 23 & & & 144,146 & 8,14 \\
\hline EGIG T47 & $71.2^{\circ} \mathrm{N}, 36.0^{\circ} \mathrm{W}$ & 3099 & -29.9 & 22 & & & 143 & 8 \\
\hline Renland $^{7,8}$ & $71.3^{\circ} \mathrm{N}, 26.7^{\circ} \mathrm{W}$ & 2340 & -18.0 & 42 & 64,88 & $5^{g}, 9^{c}$ & & \\
\hline EGIG T $53^{5}$ & $71.4^{\circ} \mathrm{N}, 32.5^{\circ} \mathrm{W}$ & 2864 & -28.0 & 23 & & & 134 & 9 \\
\hline $1987-2^{1}$ & $71.6^{\circ} \mathrm{N}, 38.1^{\circ} \mathrm{W}$ & 3157 & -30.4 & 25 & & & 128 & 5 \\
\hline EGIG NST08 ${ }^{5}$ & $71.9^{\circ} \mathrm{N}, 37.8^{\circ} \mathrm{W}$ & 3220 & -31.0 & 23 & & & 153 & 5 \\
\hline $1987-3^{1}$ & $71.9^{\circ} \mathrm{N}, 39.8^{\circ} \mathrm{W}$ & 3145 & -30.3 & 30 & & & 123 & 2 \\
\hline $1987-5^{1}$ & $72.0^{\circ} \mathrm{N}, 37.5^{\circ} \mathrm{W}$ & 3187 & -31.5 & 22 & & & 130 & 6 \\
\hline EGIG T61 ${ }^{5}$ & $72.2^{\circ} \mathrm{N}, 32.3^{\circ} \mathrm{W}$ & 2812 & -28.8 & 19 & & & 144 & 8 \\
\hline $1987-1^{1}$ & $72.3^{\circ} \mathrm{N}, 37.9^{\circ} \mathrm{W}$ & 3170 & -31.3 & 22 & & & 124 & 10 \\
\hline $1987-4^{1}$ & $72.4^{\circ} \mathrm{N}, 40.2^{\circ} \mathrm{W}$ & 3146 & -31.5 & 27 & & & 130 & 5 \\
\hline 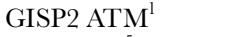 & $72.4^{\circ} \mathrm{N}, 38.8^{\circ} \mathrm{W}$ & 3200 & -32.0 & 24 & & & 120,130,135,138 & $3,5,9,3$ \\
\hline EGIG T66 $^{5}$ & $72.5^{\circ} \mathrm{N}, 30.8^{\circ} \mathrm{W}$ & 2678 & -25.7 & 17 & & & 159 & 6 \\
\hline GISP2 $^{1,9,10}$ & $72.6^{\circ} \mathrm{N}, 38.5^{\circ} \mathrm{W}$ & 3200 & -31.0 & 22 & 61,70 & $410^{\mathrm{a}}, 650^{\mathrm{a}}$ & $108,125,126,135,136,149,149,167$ & $30,7,3,6,6,2,2,2,4$ \\
\hline $\operatorname{GRIP}^{5,11,12}$ & $72.6^{\circ} \mathrm{N}, 37.6^{\circ} \mathrm{W}$ & 3232 & -31.6 & 20 & 68 & $30^{\mathrm{c}}$ & $130,138,142$ & $5,9,21$ \\
\hline $1987-7^{1}$ & $72.6^{\circ} \mathrm{N}, 35.9^{\circ} \mathrm{W}$ & 3190 & -33.1 & 18 & & & 157 & 8 \\
\hline $1990-2^{1}$ & $72.8^{\circ} \mathrm{N}, 36.5^{\circ} \mathrm{W}$ & 3200 & -33.8 & 17 & & & 136 & 1 \\
\hline $1987-6^{1}$ & $73.0^{\circ} \mathrm{N}, 37.7^{\circ} \mathrm{W}$ & 3224 & -33.8 & 17 & & & 148 & 8 \\
\hline $\mathrm{NGT}_{01}{ }^{13}$ & $73.0^{\circ} \mathrm{N}, 37.7^{\circ} \mathrm{W}$ & 3223 & -34.3 & 16 & & & 143 & 13 \\
\hline NGT03 B16 ${ }^{13}$ & $73.9^{\circ} \mathrm{N}, 37.6^{\circ} \mathrm{W}$ & 3040 & -34.6 & 12 & 85 & $40^{\mathrm{a}}$ & 132 & 23 \\
\hline North Central ${ }^{2}$ & $74.6^{\circ} \mathrm{N}, 39.6^{\circ} \mathrm{W}$ & 2930 & -32.0 & 13 & 83,112 & $9^{\mathrm{f}}, 21^{\mathrm{b}}$ & 164 & 5 \\
\hline $\mathrm{NGT} 5^{13}$ & $74.9^{\circ} \mathrm{N}, 37.6^{\circ} \mathrm{W}$ & 2873 & -35.3 & 11 & & & 189 & 12 \\
\hline NGRIP $^{8,14}$ & $75.1^{\circ} \mathrm{N}, 42.1^{\circ} \mathrm{W}$ & 2978 & -30.9 & 17 & 81 & $156^{\mathrm{a}}$ & 149,161 & 5,11 \\
\hline $\mathrm{NGT1}^{13}$ & $75.7^{\circ} \mathrm{N}, 36.4^{\circ} \mathrm{W}$ & 2671 & -34.2 & 10 & & & 161 & 14 \\
\hline NGT14 B18 ${ }^{13}$ & $76.6^{\circ} \mathrm{N}, 36.4^{\circ} \mathrm{W}$ & 2508 & -35.0 & 10 & 73 & $40^{\mathrm{a}}$ & 128 & 23 \\
\hline Camp Century $^{2}$ & $77.2^{\circ} \mathrm{N}, 61.1^{\circ} \mathrm{W}$ & 1880 & -24.4 & 35 & $46,65,71$ & $10^{\mathrm{g}}, 13^{\mathrm{d}}, 100^{\mathrm{h}}$ & 120 & 2 \\
\hline $1988-1^{1}$ & $77.2^{\circ} \mathrm{N}, 60.7^{\circ} \mathrm{W}$ & 1650 & -24.6 & 29 & & & 101 & 7 \\
\hline $1988-2,3^{1}$ & $77.2^{\circ} \mathrm{N}, 59.2^{\circ} \mathrm{W}$ & 1700 & -23.7 & 31 & & & 96,107 & 4,2 \\
\hline Camp Century II $^{2}$ & $77.2^{\circ} \mathrm{N}, 60.8^{\circ} \mathrm{W}$ & 1910 & -24.7 & 35 & 52 & $13^{\mathrm{b}}$ & & \\
\hline NGT37 B26 $6^{15}$ & $77.3^{\circ} \mathrm{N}, 49.2^{\circ} \mathrm{W}$ & 2598 & -30.0 & 18 & 69 & $440^{\mathrm{a}}$ & 110 & 24 \\
\hline NGT18 $^{13}$ & $77.5^{\circ} \mathrm{N}, 36.4^{\circ} \mathrm{W}$ & 2319 & -32.6 & 11 & & & 158 & 14 \\
\hline NGT23 B20 $0^{16}$ & $78.8^{\circ} \mathrm{N}, 36.5^{\circ} \mathrm{W}$ & 2147 & -31.5 & 10 & 83 & $1130^{\mathrm{a}}$ & 155 & 24 \\
\hline NGT27 B21 $1^{13}$ & $80.0^{\circ} \mathrm{N}, 41.1^{\circ} \mathrm{W}$ & 2185 & -29.6 & 11 & 80 & $40^{\mathrm{a}}$ & 126 & 24 \\
\hline Hans Tausen $^{8}$ & $80.5^{\circ} \mathrm{N}, 37.5^{\circ} \mathrm{W}$ & 1271 & -21.0 & 10 & 74 & $30^{\mathrm{c}}$ & 91 & 3 \\
\hline
\end{tabular}

Notes: ${ }^{1}$ Yang and others (1996), data obtained from http://nsidc.org. ${ }^{2}$ Clausen and Langway (1989). ${ }^{3}$ Mayewski and others (1990). ${ }^{4}$ Neftel and others (1985). ${ }^{5}$ Fischer and Wagenbach (1996). ${ }^{6}$ Steffensen (1988). ${ }^{7}$ Hansson (1994). ${ }^{8} \mathrm{H}$. B. Clausen, personal communication (2001). ${ }^{9}$ Yang and others (1995). ${ }^{10}$ University of Arizona, unpublished data. ${ }^{11}$ Clausen and others (1997). ${ }^{12}$ Steffensen and others (1996). ${ }^{13}$ Fischer and others (1998). ${ }^{14} \mathrm{~L}$. B. Larsen, personal communication (2001). ${ }^{15}$ Hausbrand (1998). ${ }^{16}$ Bigler (2000). ${ }^{a}$ Continuous record up to $1940 .{ }^{\mathrm{b}} 20$ th century, before $1940 .{ }^{\mathrm{c}} 19$ th century. ${ }^{\mathrm{d}} 18$ th century. ${ }^{\mathrm{e}} 11$ th to 18 th century. ${ }^{\mathrm{f}} 15$ th century. ${ }^{\mathrm{g}} 13$ th century. ${ }^{\mathrm{h}}$ Holocene.

sites, $\mathrm{NO}_{3}{ }^{-}$data from many Greenland sites have been gathered in order to illustrate the effect of temperature. Also, we outline how calcium $\left(\mathrm{Ca}^{2+}\right)$ can inhibit $\mathrm{NO}_{3}{ }^{-}$re-emission.

Another aspect that has been discussed lately is the effect on $\mathrm{NO}_{3}{ }^{-}$concentrations of snow layers containing large amounts of sulphuric acid $\left(\mathrm{H}_{2} \mathrm{SO}_{4}\right)$ of volcanic origin. Most studies focused on a few well-known volcanic eruptions during the Holocene which showed post-depositional dis- placement of $\mathrm{NO}_{3}{ }^{-}$away from the $\mathrm{H}_{2} \mathrm{SO}_{4}$ peak. This behaviour has been found in single events in Greenland and Antarctica (Legrand and Kirchner, 1990; Clausen and others, 1997; Röthlisberger and others, 2000a). However, the mechanisms leading to this effect are only vaguely understood, and hypotheses have not been tested on a large number of cases, because of a lack of sufficient high-resolution data.

In this paper, new high-resolution data from the North- 


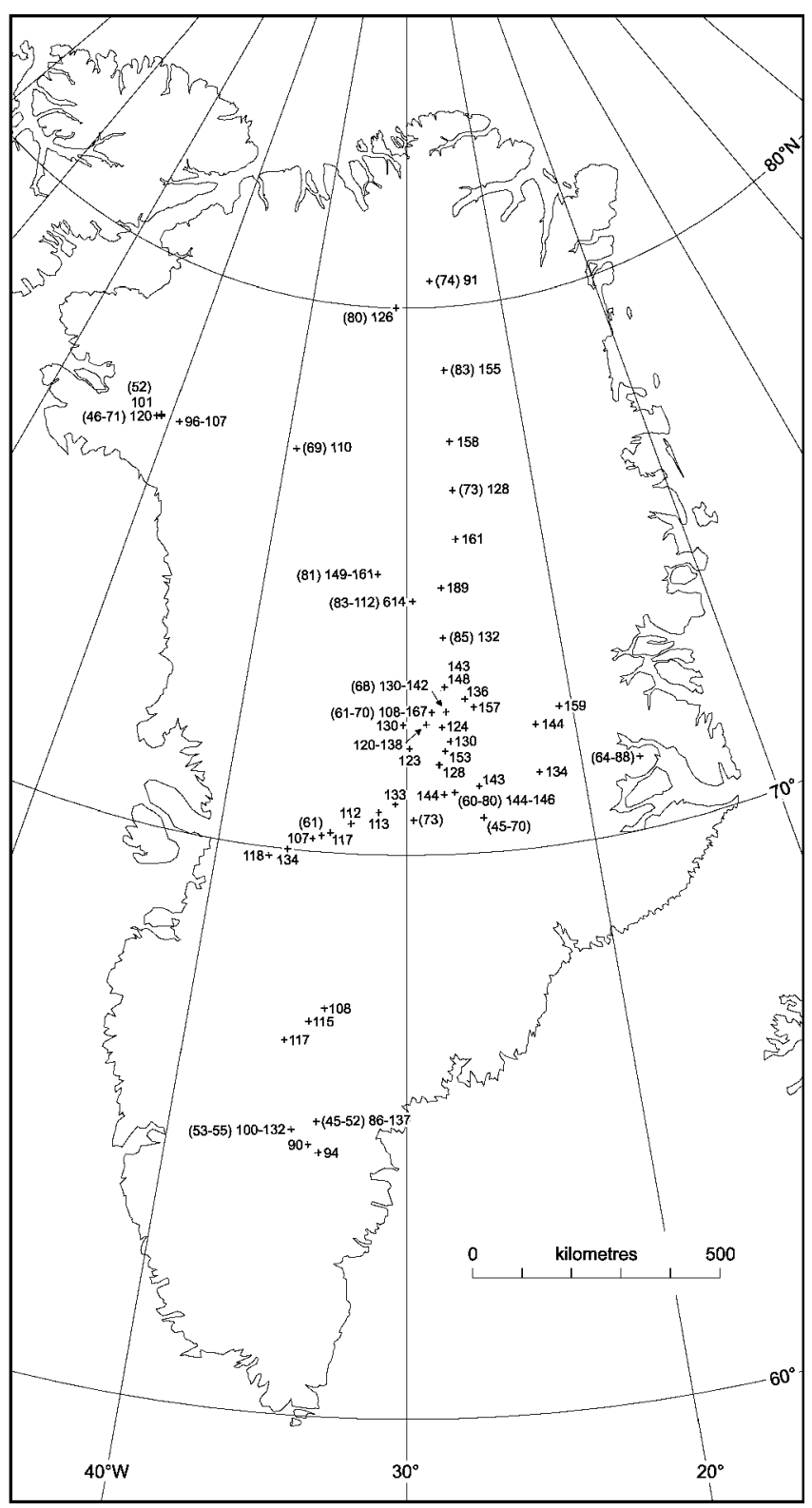

Fig. 1. Spatial distribution of $\mathrm{NO}_{3}^{-}$across Greenland. Concentrations in snow deposited before 1940 are shown in parentheses; the other values correspond to concentrations in snow deposited after 1970. All concentrations are in ppb.

GRIP (North Greenland Ice Core Project) ice core are used to investigate in more detail the effect of volcanic $\mathrm{H}_{2} \mathrm{SO}_{4}$ on $\mathrm{NO}_{3}{ }^{-}$. Volcanic events from the early Holocene, the Last Glacial Maximum (LGM) and some earlier glacial periods are compared and a hypothesis of the mechanism is given.

\section{DATA}

Many of the $\mathrm{NO}_{3}{ }^{-}$data used in this paper are compiled from earlier studies (see Table 1 for sources). Furthermore, data from selected sections of the NorthGRIP ice core $\left(75.1^{\circ} \mathrm{N}\right.$, $42.05^{\circ} \mathrm{W} ; 2978 \mathrm{~m}$ a.s.l.) are presented. These sections were analyzed during the NorthGRIP 2000 field season with a continuous flow analysis (CFA) system, as described in Röthlisberger and others (2000b). Among other compounds, nitrate $\left(\mathrm{NO}_{3}{ }^{-}\right)$, sulphate $\left(\mathrm{SO}_{4}{ }^{2-}\right)$ and calcium $\left(\mathrm{Ca}^{2+}\right)$ have been measured at a resolution of approximately $1 \mathrm{~cm}$.

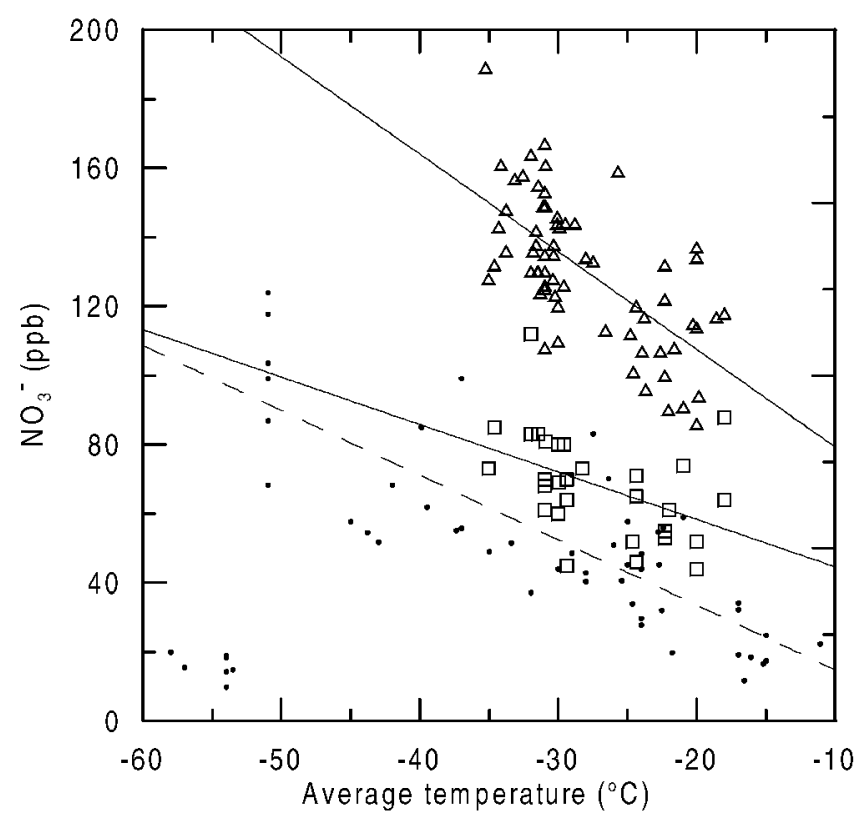

Fig. 2. $\mathrm{NO}_{3}{ }^{-}$concentrations vs average temperatures in Greenland and Antarctica with linear trends (triangles: post-1970; squares: pre-1940; solid lines: Greenland; dots and dashed line: Antarctica). The data points at temperatures below $-52^{\circ} \mathrm{C}$ correspond to sites with very low accumulation rates and are not used for the calculation of the linear fit shown.

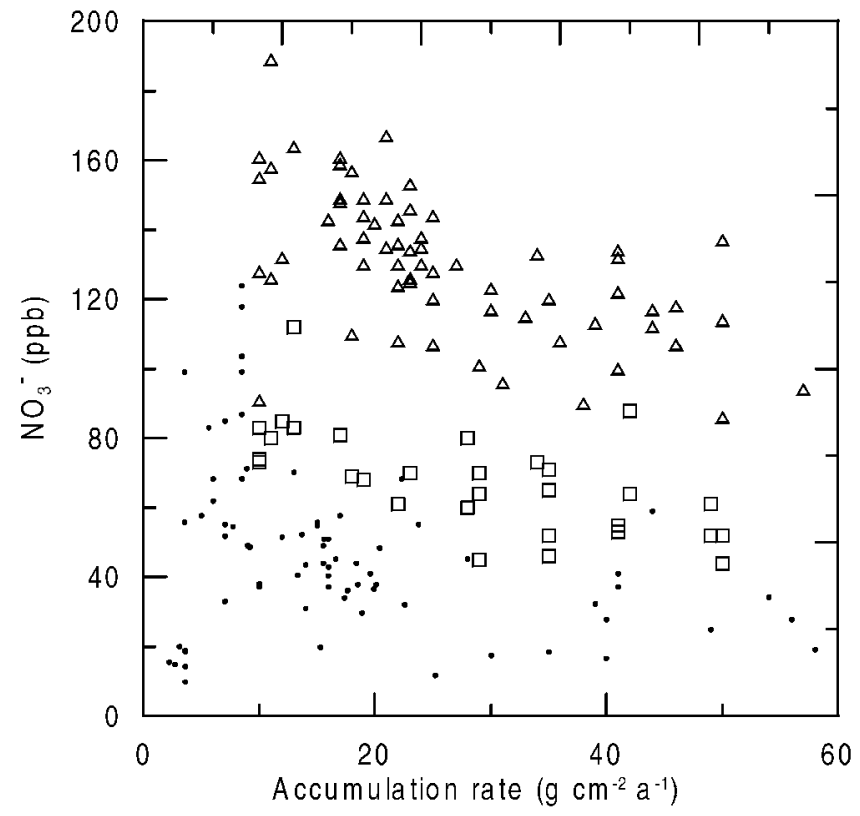

Fig. 3. $\mathrm{NO}_{3}^{-}$concentrations vs accumulation rate in Greenland and Antarctica (triangles: post-1970; squares: pre-1940; dots: Antarctica).

\section{$\mathrm{NO}_{3}{ }^{-}$, TEMPERATURE AND ACGUMULATION RATE}

In Figure 1, average $\mathrm{NO}_{3}{ }^{-}$concentrations for different Greenland locations are indicated. In order to account for the anthropogenic increase in $\mathrm{NO}_{3}{ }^{-}$concentrations in Greenland, the data have been split into two separate sets, one indicating concentrations from before 1940, which are unaffected by the anthropogenic emissions, and one from after 1970. The data and their sources are listed in Table 1. For both pre-1940 and post-1970, a decreasing trend in $\mathrm{NO}_{3}{ }^{-}$concentration with increasing temperature is found (Fig. 2). A similar trend has been found in Antarctica (Röthlisberger and others, 2000a), 


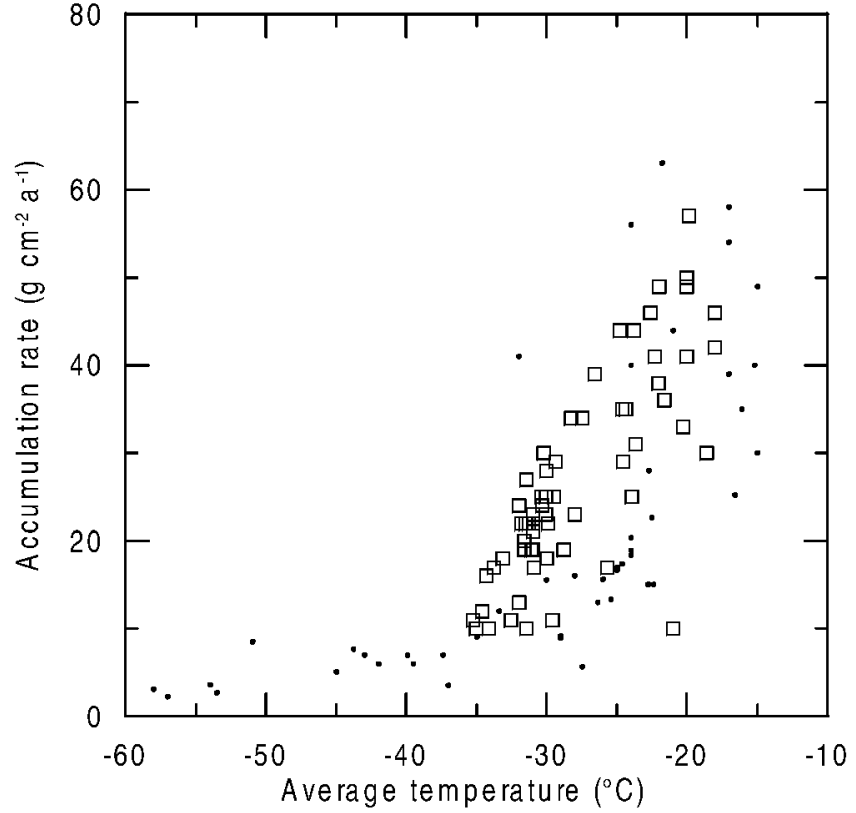

Fig. 4. Accumulation rate vs average temperatures in Greenland and Antarctica (squares: Greenland; dots: Antarctica).

where also generally higher concentrations are found at sites with lower temperatures, except for very low-accumulation sites (e.g. Dome G). At Dome C, the concentrations in the top few centimetres can be very high (up to $1000 \mathrm{ppb}$ ), but at greater depths, only $15 \mathrm{ppb}$ are preserved, despite the low temperatures (annual mean temperature $\approx-54^{\circ} \mathrm{C}$ ).

When $\mathrm{NO}_{3}{ }^{-}$concentrations are plotted against accumulation rate, higher $\mathrm{NO}_{3}{ }^{-}$concentrations are found at sites with lower accumulation rates (Fig. 3), but again, $\mathrm{NO}_{3}{ }^{-}$concentrations at very low-accumulation sites do not agree with the general trend. Considering the close relationship between temperature and accumulation rate (Fig. 4), it seems difficult to separate their effects on $\mathrm{NO}_{3}{ }^{-}$concentrations. Only a detailed consideration of the underlying microphysical processes allows for assigning a temperature or accumulationrate dependence.

In the following discussion, we analyze the temperature and accumulation-rate dependence of processes involved in $\mathrm{NO}_{3}{ }^{-}$deposition and re-emission, aiming for a better understanding of:

the cause of the relationship between $\mathrm{NO}_{3}{ }^{-}$concentrations and mean annual temperature and accumulation rate at a site

the generally higher $\mathrm{NO}_{3}{ }^{-}$levels in summer snow than in winter snow

the net loss of $\mathrm{NO}_{3}{ }^{-}$from snow after deposition.

$\mathrm{NO}_{3}{ }^{-}$can either be predominantly incorporated in the bulk or be adsorbed to the surface of a snow crystal, depending on the deposition pathway. In a cloud with a liquid-water content of $>0.01 \mathrm{~g} \mathrm{~m}^{-3}$ and $\mathrm{pH}>1, \mathrm{HNO}_{3}$ would be completely dissolved in water droplets due to its high solubility, leaving virtually no $\mathrm{HNO}_{3}$ in the gas phase (Seinfeld and Pandis, 1998). Thus, in the case of liquid or mixed clouds, essentially all $\mathrm{HNO}_{3}$ is removed from the gas phase independent of the cloud temperature. While there is no specific information about the conditions at cloud level, typical liquidwater contents of $0.1 \mathrm{~g} \mathrm{~m}^{-3}$ and initial $\mathrm{HNO}_{3}$ concentrations of $20 \mathrm{pptv}$ in the air would lead to $\mathrm{NO}_{3}{ }^{-}$concentrations of
Table 2. Estimates of $\mathrm{NO}_{3}^{-}$concentrations in snow due to different deposition mechanisms

\begin{tabular}{|c|c|c|c|c|c|c|}
\hline & \multicolumn{2}{|c|}{ Summit } & \multicolumn{2}{|c|}{ Neumayer } & \multicolumn{2}{|c|}{ South Pole } \\
\hline & Summe & Winter & Summer & Winter & Summe & Winter \\
\hline Pressure $(\mathrm{Pa})$ & \multicolumn{2}{|c|}{67000} & \multicolumn{2}{|c|}{99000} & \multicolumn{2}{|c|}{68000} \\
\hline $\begin{array}{l}\text { Accumulation rate } \\
\left(\mathrm{g} \mathrm{cm}^{-2} \mathrm{a}^{-1}\right)\end{array}$ & \multicolumn{2}{|c|}{20} & \multicolumn{2}{|c|}{34} & \multicolumn{2}{|c|}{8.5} \\
\hline Temperature $(\mathbf{K})$ & 259 & 230 & 269 & 247 & 246 & 208 \\
\hline Relative humidity & 0.75 & 0.75 & 0.8 & 0.8 & 0.75 & 0.6 \\
\hline $\mathrm{HNO}_{3}$ atm. (pptv) & 20 & 1 & 6 & 1 & 20 & 1 \\
\hline $\mathrm{NO}_{3}{ }^{-}$snow (ppbw) & \multicolumn{2}{|c|}{120} & \multicolumn{2}{|c|}{50} & \multicolumn{2}{|c|}{100} \\
\hline $\begin{array}{l}\text { Co-condensation } \\
\quad(\text { ppbw })\end{array}$ & 7 & 9 & 1 & 2 & 26 & 160 \\
\hline Solubility in ice (ppbw) & 19 & 29 & 8 & 12 & 40 & 150 \\
\hline Surface uptake (ppbw) & & 1900 & & 780 & 840 & 3300 \\
\hline Dry deposition (ppbw) & 30 & 2 & 8 & 1 & 77 & 5 \\
\hline
\end{tabular}

Note: The meteorological data are from automatic weather stations; the atmospheric $\mathrm{HNO}_{3}$ summer concentrations are from Dibb and others (1994) and Jones and others (1999). For South Pole, atmospheric concentrations of the same order of magnitude as in Summit have been assumed. The $\mathrm{HNO}_{3}$ winter concentration has only been measured at Neumayer and has been found to be approximately 1 pptv (personal communication from R. Weller, 2001). In the absence of measurements for the other sites, we assume the winter concentrations at Summit and South Pole are the same as in Neumayer. The calculations for co-condensation and solubility in ice are based on Thibert and Dominé (1998). Surface uptake was estimated using a linear regression through the values for temperaturedependent uptake found by Abbatt (1997) and assuming a typical surface area of $4000 \mathrm{~m}^{2} \mathrm{~m}^{-3}$ (Narita, 1971). Temperatures higher than $248 \mathrm{~K}$ have not been included in the study of surface uptake, so the estimates for surface uptake in Summit and Neumayer during summer are missing. Dry deposition was calculated assuming a dry-deposition velocity of $0.5 \mathrm{~cm} \mathrm{~s}^{-1}$ (Hauglustaine and others, 1994).

approximately $350 \mathrm{ppbw}$ in fresh snow. On the other hand, the co-condensation of $\mathrm{HNO}_{3}$ and water $\left(\mathrm{H}_{2} \mathrm{O}\right)$ molecules on ice crystals (Thibert and Dominé, 1998) would lead to a bulk concentration of 20 ppbw only. In the absence of liquid water, i.e. in ice clouds, the high $\mathrm{NO}_{3}{ }^{-}$concentrations found in surface snow could not be explained. However, Abbatt (1997) observed a temperature dependence of adsorption of $\mathrm{HNO}_{3}$ on ice surfaces with higher uptake at lower temperatures. For typical summer temperatures at South Pole (246 K; data obtained from http://www.cmdl.noaa.gov), the uptake capacity on fresh snow crystals exceeds the amount of $\mathrm{HNO}_{3}$ available in the cloud, implying that at very cold temperatures where ice clouds predominate, essentially all $\mathrm{HNO}_{3}$ in a cloud is bound to the surface of the snow crystal. While co-condensation, riming and adsorption of $\mathrm{HNO}_{3}$ determine the distribution of $\mathrm{NO}_{3}{ }^{-}$within the ice crystal, its concentration is defined by the initial atmospheric concentration of $\mathrm{HNO}_{3}$ and the amount of condensed water in the cloud. An imprint of temperature is expected for surface uptake and co-condensation, but not for the $\mathrm{HNO}_{3}$ taken up in liquid cloud droplets. Based on the results of Abbatt (1997), the snow crystals are expected to efficiently scavenge atmospheric $\mathrm{HNO}_{3}$ on their way to the surface, potentially further increasing the $\mathrm{NO}_{3}{ }^{-}$concentration of the fresh snow.

Once on the ground, the formation of surface hoar frost (co-condensation), rime (deposition of supercooled fog droplets) as well as dry deposition (adsorption of $\mathrm{HNO}_{3}$ onto the crystal's surface) leads to additional $\mathrm{NO}_{3}{ }^{-}$deposition to surface snow. For a given atmospheric $\mathrm{HNO}_{3}$ concentration, the hoar-frost $\mathrm{NO}_{3}{ }^{-}$concentration is determined by the water- 

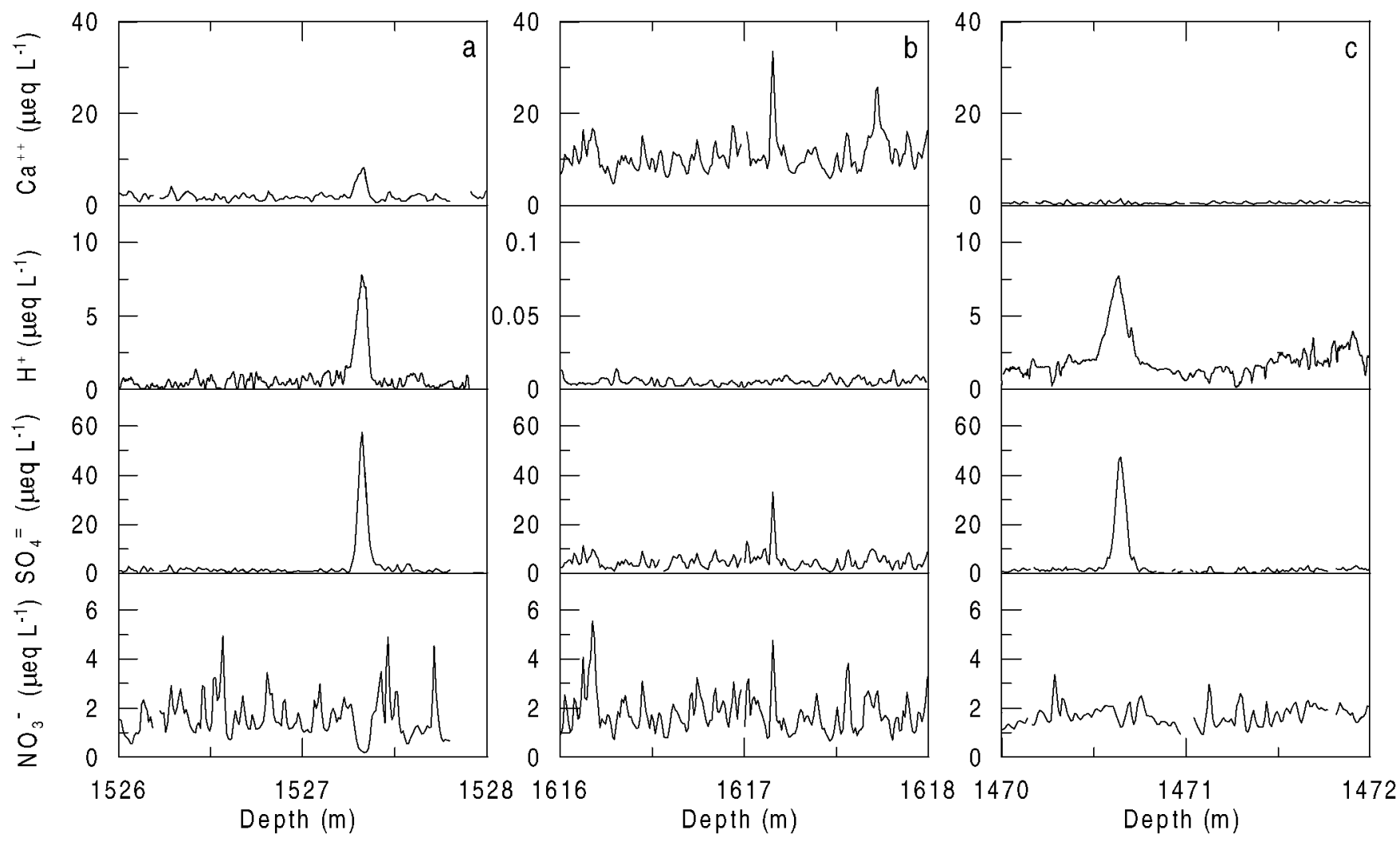

Fig. 5. Examples of the influence of volcanic $\mathrm{H}_{2} \mathrm{SO}_{4}$ on $\mathrm{NO}_{3}{ }_{3}$ in the NorthGRIP ice core. $\mathrm{H}^{+}$concentrations have been inferred from electrical conductivity measurements on the solid ice. Due to very low $\mathrm{H}^{+}$concentrations, the scale of the $y$ axis had to be adjusted for the section shown in (b). Of 28 events selected with $\mathrm{SO}_{4}^{2}$ concentrations exceeding $20 \mu e q L^{-1}, 14$ showed a pattern similar to ( $a$ ), 12 similar to ( $b$ ), and 2 similar to $(c)$. The data are shown against depth, as the absolute age is not critical to the illustration of the effect and an absolute time-scale is not yet available.

vapour concentration (Thibert and Dominé, 1998), which is mainly a function of temperature $T$. Assuming that the relative humidity at the site is similar throughout the year, the $\mathrm{NO}_{3}{ }^{-}$concentration should depend linearly on $1 / T$ in a first-order approach. However, assuming that the $\mathrm{HNO}_{3}$ concentrations in the atmosphere as in Table 2 are representative for the site, the estimated concentrations resulting from co-condensation are lower than observed surface snow concentrations, thus leading to dilution of the surface snow (Table 2). Rime deposition, on the other hand, which is likely to remove all $\mathrm{HNO}_{3}$ from the air, shows concentrations similar to those in fresh snow, provided that the atmospheric $\mathrm{HNO}_{3}$ concentration is similar to that at cloud level. A net dry deposition of $\mathrm{HNO}_{3}$ (adsorption of $\mathrm{HNO}_{3}$ onto snow crystals) has the potential to increase the $\mathrm{NO}_{3}{ }^{-}$concentration in snow. However, it will only contribute where the surface is undersaturated, i.e. at very cold sites and during winter. The contribution in winter is small, due to low atmospheric $\mathrm{HNO}_{3}$ concentrations. During the summer, the contribution of dry deposition to the $\mathrm{NO}_{3}{ }^{-}$concentrations in snow at South Pole might be considerable. However, according to Hauglustaine and others, (1994), the dry-deposition velocity of $0.5 \mathrm{~cm} \mathrm{~s}^{-1}$ for $\mathrm{HNO}_{3}$ on snow has to be considered as an upper limit. At sites with higher accumulation rates, a specific surface snow layer is buried more rapidly, leaving less time to adsorb additional $\mathrm{HNO}_{3}$ from the atmosphere, given that no saturation has been reached. Therefore, a tendency to higher concentrations at lower accumulation rates is expected.

Besides the diluting effect of co-deposition, processes capable of reducing the $\mathrm{NO}_{3}{ }^{-}$concentration in snow are desorp- tion of $\mathrm{HNO}_{3}$ from the snow crystal (Dibb and others, 1998; Mulvaney and others, 1998; Röthlisberger and others, 2000a) and photolysis (Honrath and others, 2000; Jones and others, 2000). In both cases, the $\mathrm{NO}_{3}{ }^{-}$ion has to be at the surface of a snow crystal, since photolysis of $\mathrm{NO}_{3}{ }^{-}$in the bulk is not effective (Dubowski and others, 2001). If a $\mathrm{NO}_{3}{ }^{-}$ion recombines with a $\mathrm{H}^{+}$ion to form $\mathrm{HNO}_{3}$, it then may desorb into the firn air and eventually diffuse into the air above the snow. Diffusion of $\mathrm{NO}_{3}{ }^{-}$in ice has been investigated by Thibert and Dominé (1998), who found that diffusion of $\mathrm{NO}_{3}{ }^{-}$in ice is slower at colder temperatures, with the diffusion coefficient $D$ given by $D=1.37 \times 10^{-2610 / T} \mathrm{~cm}^{2} \mathrm{~s}^{-1}$, with $T$ being the temperature in $\mathrm{K}$. During the summer, the typical time a $\mathrm{NO}_{3}{ }^{-}$ molecule needs to reach the ice surface (diffusion length of $40 \mu \mathrm{m}$, corresponding to an average crystal radius (Harder and others, 1996)) is of the order of a couple of hours (e.g. Neumayer) to a few days (e.g. South Pole).

The solubility of $\mathrm{NO}_{3}{ }^{-}$in ice has been determined for various temperatures (Thibert and Dominé, 1998). For summer conditions, not only the surface snow but also deeper layers are supersaturated with respect to the solubility of $\mathrm{NO}_{3}{ }^{-}$in ice (Table 2). In the case of South Pole, the surface remains undersaturated, suggesting that $\mathrm{NO}_{3}{ }^{-}$that is expelled from the bulk is simply transferred to the surface without affecting the $\mathrm{NO}_{3}{ }^{-}$concentration. At warmer sites (e.g. Neumayer or Summit), the ice surface also might become supersaturated during the summer, leading to release of $\mathrm{HNO}_{3}$ from the snow into the interstitial air. From a thermodynamic point of view, warmer temperatures during the summer should facilitate the release of $\mathrm{HNO}_{3}$ from the ice surface. But according to the uptake experiment of Abbatt (1997), only up to $25 \%$ of the 
$\mathrm{HNO}_{3}$ that has been taken up is released again afterwards. However, his study emphasized the uptake rather than the release of $\mathrm{HNO}_{3}$, and a temperature dependence of the release has not been discussed. Once released from the snow crystal's surface, the $\mathrm{HNO}_{3}$ molecule might make its way out of the snowpack, leading to a net loss of $\mathrm{NO}_{3}{ }^{-}$in the snow. The molecular diffusion of $\mathrm{HNO}_{3}$ in the interstitial air is temperature-dependent as well, but probably this is not the limiting factor controlling the transfer out of the snowpack. It is conceivable that temperature-dependent, repeated adsorption and subsequent desorption of a $\mathrm{HNO}_{3}$ molecule on ice crystals will determine the removal from the snowpack.

Photolysis of $\mathrm{NO}_{3}{ }^{-}$in the top snow layers results in the production of nitrogen dioxide $\left(\mathrm{NO}_{2}\right)$ and hydroxyl radical $(\mathrm{OH}) . \mathrm{NO}_{2}$ is expected not to interact with the surrounding snow but to be mixed into the boundary layer rather quickly, leading to a $\mathrm{NO}_{3}{ }^{-}$depletion in surface snow. The influence is presumably largest at low-accumulation sites, where surface snow is exposed to sunlight for a long time. Furthermore, photolysis should become more efficient at lower latitudes due to more incoming ultraviolet radiation. At Dome $\mathrm{G}$, the top few centimetres of snow seem to reach saturated surface coverage (concentrations in the range of several hundred ppbw) (Röthlisberger and others, 2000b). Deeper layers are then dramatically undersaturated considering surface coverage and solubility in the bulk. No quantitative estimate has yet been made of how much $\mathrm{NO}_{3}{ }^{-}$can be lost by photolysis. It therefore remains unclear whether photolysis alone can account for the $\mathrm{NO}_{3}{ }^{-}$profile seen in the snow at Dome $\mathrm{C}$. The estimate of the maximum surface uptake relies very much on the surface area in snow and might change due to recrystallization, which has not yet been taken into account.

Although elevation may affect the atmospheric $\mathrm{HNO}_{3}$ concentration, there is no obvious mechanism by which it can have a direct physical influence on post-depositional processes. A minor influence is expected on the photolysis rate due to changes in the irradiance with altitude and on the gas-phase diffusion due to lower pressure, but both effects might only slightly modulate the changes in $\mathrm{NO}_{3}$ concentrations.

\section{INTERAGTIONS OF $\mathrm{NO}_{3}{ }^{-}$WITH DUST}

Recent studies have reported that $\mathrm{NO}_{3}{ }^{-}$and $\mathrm{Ca}^{2+}$ concentrations are correlated in ice from the last glacial period from Vostok and Dome C, Antarctica (Legrand and others, 1999; Röthlisberger and others, 2000a). During the last glacial period, the $\mathrm{Ca}^{2+}$ deposited on the East Antarctic plateau is mainly of terrestrial origin and can thus be used as a proxy for dust. It has been suggested that the reaction of $\mathrm{HNO}_{3}$ and $\mathrm{CaCO}_{3}$ to form $\mathrm{Ca}\left(\mathrm{NO}_{3}\right)_{2}$ prevents $\mathrm{NO}_{3}{ }^{-}$from being released from the snow into the gas phase.

In principle, the reaction could take place in the atmosphere or in the snow. For it to occur in the atmosphere, high dust concentrations would need to be in the same season as the maximum nitrate concentrations. A recent paper that studied the reaction of $\mathrm{CaCO}_{3}$ with $\mathrm{HNO}_{3}$ derived a formula for the lifetime for removal of $\mathrm{HNO}_{3}$ by dust (Hanisch and Crowley, 2001). Based on this, and using very rough estimates for the surface area of dust (assuming spherical particles of $1 \mu \mathrm{m}$ diameter, a typical density of $2 \mathrm{~g} \mathrm{~cm}^{-3}$, and atmospheric dust concentrations of $10 \mathrm{ng} \mathrm{m}^{-3}$ ), we can estimate a $\mathrm{HNO}_{3}$ lifetime vs removal by dust in the present-day Antarctic atmosphere of around 50 days. This is unlikely to be important relative to other removal processes. However, this could be reduced to 2 days under the dustier conditions of the LGM, and in Greenland under LGM conditions one could estimate a lifetime for this removal of only a few hours. It seems possible therefore that under LGM conditions much of the atmospheric $\mathrm{HNO}_{3}$ could be converted to aerosol calcium nitrate in the atmosphere. In addition, the reaction to form $\mathrm{Ca}\left(\mathrm{NO}_{3}\right)_{2}$ might take place in the snow, in which case $\mathrm{HNO}_{3}$ has to make its way to the snow layer where the $\mathrm{Ca}^{2+}$ has been deposited and, if $\mathrm{Ca}^{2+}$ is inside the snow grain rather than on its surface, diffuse through it.

\section{INFLUENGE OF VOLGANIC $\mathrm{H}_{2} \mathrm{SO}_{4} \mathrm{ON} \mathrm{NO}_{3}{ }^{-}$}

As shown lately in an Antarctic high-resolution record from Dome $\mathrm{C}$ (Röthlisberger and others, 2000a), $\mathrm{H}_{2} \mathrm{SO}_{4}$ of volcanic origin can cause $\mathrm{NO}_{3}{ }^{-}$to move in the ice. Several examples of very low $\mathrm{NO}_{3}{ }^{-}$concentrations coinciding with $\mathrm{H}_{2} \mathrm{SO}_{4}$ peaks and increased $\mathrm{NO}_{3}{ }^{-}$concentrations above and below this layer have been found in the Dome $\mathrm{C}$ as well as the NorthGRIP record (Fig. 5a). At Dome $\mathrm{C}$, the effect is first seen at $12 \mathrm{~m}$ depth, where the deposits of the Tambora (Indonesia) eruption (AD 1815) are located. This indicates that the processes involved take place or at least start in the firn.

Our hypothesis of the mechanism for $\mathrm{NO}_{3}{ }^{-}$displacement in the firn relies on processes similar to those described above, as it includes diffusion of $\mathrm{HNO}_{3}$ in the firn air. The high concentration of $\mathrm{H}_{2} \mathrm{SO}_{4}$ in a volcanic layer causes the equilibrium of $\mathrm{H}^{+}+\mathrm{NO}_{3}{ }^{-} \rightleftharpoons \mathrm{HNO}_{3}$ to shift towards the righthand side, as a large amount of $\mathrm{H}^{+}$from the $\mathrm{H}_{2} \mathrm{SO}_{4}$ is present. Therefore, a locally elevated concentration of $\mathrm{HNO}_{3}$ in the firn air is caused, which prompts gas-phase diffusion of the $\mathrm{HNO}_{3}$ away from the volcanic layer towards either side. In an adjacent layer with no excessive $\mathrm{H}_{2} \mathrm{SO}_{4}, \mathrm{HNO}_{3}$ favours dissociation into $\mathrm{H}^{+}$and $\mathrm{NO}_{3}{ }^{-}$, thus maintaining the gradient in the firn air by removing $\mathrm{HNO}_{3}$ from the gas phase. It is possible that the movement of $\mathrm{NO}_{3}{ }^{-}$progresses via a different mechanism in the ice after pore close-off, possibly by diffusion of ions in the veins.

Figure $5 \mathrm{~b}$ shows an event where no $\mathrm{NO}_{3}{ }^{-}$displacement occurred. In this section, large amounts of alkaline material are present in the ice, as seen by the high $\mathrm{Ca}^{2+}$ and negligible $\mathrm{H}^{+}$concentrations. In the context of the above hypothesis, the high concentrations of alkaline material (presumably $\mathrm{CaCO}_{3}$ ) neutralize the $\mathrm{H}_{2} \mathrm{SO}_{4}$ and prevent the formation of $\mathrm{HNO}_{3}$. The assumption that in this case $\mathrm{H}_{2} \mathrm{SO}_{4}$ undergoes some reactions is supported by the significantly narrower $\mathrm{SO}_{4}{ }^{2-}$ peak compared to the ones seen in acid ice (personal communication from P. Barnes, 2001).

Our hypothesis is challenged by the example shown in Figure 5c. Although much excess $\mathrm{H}_{2} \mathrm{SO}_{4}$ is present and far too little $\mathrm{Ca}^{2+}$ to compensate, no marked $\mathrm{NO}_{3}{ }^{-}$displacement is seen. It is possible that the $\mathrm{Ca}^{2+}$ was unable to neutralize the $\mathrm{H}_{2} \mathrm{SO}_{4}$, but that it managed to bind $\mathrm{NO}_{3}{ }^{-}$, thus preventing it from being transferred into the gas-phase. The occurrence of ice layers limiting $\mathrm{HNO}_{3}$ diffusion in the interstitial air is rather unlikely in NorthGRIP.

\section{GONGLUSIONS}

The spatial distribution of nitrate concentrations in Greenland is shown to be strongly related to site temperature, just as it is 
for Antarctica. Because temperature and snow-accumulation rate are so closely linked, we cannot determine which of these factors is the one exerting physical control on the concentrations seen. In either case, the relationship changes at the very lowest accumulation rates, where it is clear that post-depositional losses are the dominant control on the subsurface concentration.

By examining the individual processes that could contribute to the nitrate concentration in snow, we find that many of them are indeed temperature-dependent, with higher concentrations predicted at lower temperatures, as observed. Some processes could also depend on the accumulation rate, if a longer exposure time at the surface allows additional uptake. Of the processes identified, either uptake by liquid droplets in cloud, if present, or uptake onto the ice surface in the cloud or after deposition can lead to concentrations in fresh snow that are as high as or higher than those observed. However, the role of surface uptake at higher temperatures, as encountered in coastal Antarctica and in Greenland in summer, needs to be quantified. Co-condensation of nitric acid and water, and dissolution of nitric acid within the ice lattice appear to give concentrations that are too low compared to those observed. This suggests tentatively that surface uptake and retention might be rather important in determining the concentrations we see. This process has a temperature dependence (approximately threefold greater uptake at $-55^{\circ} \mathrm{C}$ compared to $-25^{\circ} \mathrm{C}$ (Abbatt, 1997) ) similar to that seen in Figure 2. However, according to Abbatt (1997), the uptake is not dependent on the nitric acid concentration in air. The higher nitrate concentrations in post-1970 Greenland snow compared to pre1940 snow suggest that the snow concentration is somehow related to atmospheric concentrations, and we suggest that this is simply a question of limited supply to the ice surface, because nitric acid is scavenged so efficiently. In that case, a temperature- and accumulation-rate-corrected Holocene nitrate ice-core record of a site with adequate snow-accumulation rate should reflect the flux of nitrate to the surface, which should in turn be related to atmospheric $\mathrm{NO}_{x}$ input.

For sites with very low accumulation rate, losses, possibly due to photolysis, control the concentration seen in the Holocene in such a dominant way that it is unlikely that information about atmospheric nitrate or $\mathrm{NO}_{x}$ can be extracted. Once the ice becomes less acidic (in the last glacial period), the concentration of nitrate seems to be strongly controlled by the calcium or dust content of the atmosphere, and the deposition processes might be significantly altered. The ratio of nitrate to dust might give clues to the past nitrate content of the atmosphere, although in this case it is probable that the nitrate uptake is determined by the content of the atmosphere over the whole transport route of dust from its source to the deposition site, and is not closely related to the local nitrate concentration at the ice-core site.

A number of laboratory and field experiments would help to test the above hypotheses. Laboratory uptake experiments, similar to those carried out at $248 \mathrm{~K}$ and below (Abbatt, 1997), are needed at higher temperatures, appropriate to summer temperatures at coastal Antarctic or Greenland sites. Laboratory experiments would also allow an assessment of whether photolysis can account for the magnitude of nitrate losses at low-accumulation sites. Field measurements of the nitric acid content of the atmosphere are lacking for most sites, and particularly for winter. Experiments that follow the evolution of concentration from fresh snow to depth in individual layers are also required.
In summary, the factors that control nitrate concentration in ice cores are complex, and interpretation is likely to involve different factors for different locations and time periods. However, if the factors controlling deposition and loss can be better understood, it may still be possible, in some cases, to reconstruct information about the important $\mathrm{NO}_{x}$ cycle in the past.

\section{ACKNOWLEDGEMENTS}

This work was supported by a fellowship of the Swiss National Science Foundation. We thank H. B. Clausen and L. B. Larsen for providing unpublished nitrate data. Thanks to NorthGRIP participants and supporters as well as its funding agencies.

\section{REFERENCES}

Abbatt, J. P. D. 1997. Interaction of $\mathrm{HNO}_{3}$ with water-ice surfaces at temperatures of the free troposphere. Geophys. Res. Lett., 24(12), 1479-1482.

Bigler, M. 2000. Entwicklung und Anwendung einer neuen Methode zur kontinuierlichen, hochaufgelösten Messung der Sulfatkonzentration an alpinen und polaren Eisbohrkernen. (M.Sc. thesis, University of Bern.)

Clausen, H. B. and C. C. Langway, Jr. 1989. The ionic deposits in polar ice cores. In Oeschger, H. and C. C. Langway, Jr, eds. The environmental record in glaciers and ice sheets. Chichester, etc., John Wiley and Sons, 225-247.

Clausen, H. B. and 6 others. 1997. A comparison of the volcanic records over the past 4000 years from the Greenland Ice Core Project and DYE 3 Greenland ice cores. 7. Geophys. Res., 102(C12), 26,707-26,723.

Dibb, J. E., R.W. Talbot and M. H. Bergin. 1994. Soluble acid species at Summit, Greenland. Geophys. Res. Lett., 21(15), 1627-1630.

Dibb, J. E., R. W. Talbot, J.W. Munger, D. J. Jacob and S. M. Fan. 1998. Airsnow exchange of $\mathrm{HNO}_{3}$ and $\mathrm{NO}_{y}$ at Summit, Greenland. 7. Geophys. Res., 103(D3), 3475-3486.

Dubowski, V., A. J. Colussi and M. R. Hoffmann. 2001. Nitrogen dioxide release in the $302 \mathrm{~nm}$ band photolysis and spray-frozen aqueous nitrate solutions: atmospheric implications. F. Phys. Chem., Ser. A, 105(20), 4928-4932

Fischer, H. and D. Wagenbach. 1996. Large-scale spatial trends in recen firn chemistry along an east-west transect through central Greenland. Atmos. Environ., 30(19), 3227-3238.

Fischer, H., D. Wagenbach and J. Kipfstuhl. 1998. Sulfate and nitrate firn concentrations on the Greenland ice sheet. 1. Large-scale geographical deposition changes. F. Geophys. Res., 103(D17), 21,927-21,934.

Hanisch, F. and J. N. Crowley. 2001. Hetereogeneous reactivity of gaseous nitric acid on $\mathrm{Al}_{2} \mathrm{O}_{3}, \mathrm{CaCO}_{3}$, and atmospheric dust samples: a Knudsen cell study. F. Phys. Chem., Ser. A, 105(13), 3096-3106.

Hansson, M. E. 1994. The Renland ice core: a Northern Hemisphere record of aerosol composition over 120000 years. Tellus, 46B (5), 390-418.

Harder, S. L., S. G. Warren, R. J. Charlson and D. S. Covert. 1996. Filtering of air through snow as a mechanism for aerosol deposition to the Antarctic ice sheet. F. Geophys. Res., 101(D13), 18,729-18743.

Hauglustaine, D. A., C. Granier, G. P. Brasseur and G. Mégie. 1994. The importance of atmospheric chemistry in the calculation of radiative forcing on the climate system. 7. Geophys. Res., 99(D1), 1173-1184.

Hausbrand, R. 1998. Direktmessung der Azidität in einem Eisbohrkern aus Nordwestgrönland. (M.Sc. thesis, University of Heidelberg.

Herron, M. M. 1982. Impurity sources of $\mathrm{F}^{-}, \mathrm{Cl}^{-}, \mathrm{NO}_{3}{ }^{-}$and $\mathrm{SO}_{4}{ }^{2-}$ in Greenland and Antarctic precipitation. 7. Geophys. Res., 87(C4), 3052-3060.

Honrath, R. E., S. Guo, M. C. Peterson, M. P. Dziobak, J. E. Dibb and M. A. Arsenault. 2000. Photochemical production of gas phase $\mathrm{NO}_{x}$ from ice crystal $\mathrm{NO}_{3}{ }^{-}$. 7. Geophys. Res., 105(D19), 24,183-24,190.

Jones, A. E. and 8 others. 1999. Oxidized nitrogen chemistry and speciation in the Antarctic troposphere. 7. Geophys. Res., 104(D17), 21,355-21,366.

Jones, A. E., R. Weller, E. W. Wolff and H.-W. Jacobi. 2000. Speciation and rate of photochemical NO and $\mathrm{NO}_{2}$ production in Antarctic snow. Geophys. Res. Lett., 27(3), 345-348.

Kreutz, K. J. and P. A. Mayewski. 1999. Spatial variability of Antarctic surface snow glaciochemistry: implications for paleoatmospheric circulation reconstructions. Antarct. Sci., 11 (1), 105-118.

Legrand, M. R. and S. Kirchner. 1990. Origins and variations of nitrate in south polar precipitation. F. Geophys. Res., 95(D4), 3493-3507.

Legrand, M., E. Wolff and D. Wagenbach. 1999. Antarctic aerosol and snowfall chemistry: implications for deep Antarctic ice-core chemistry. Ann. Glaciol., 29, 66-72.

Mayewski, P. A., W. B. Lyons, M. J. Spencer, M. S. Twickler, C. F. Buck and S. 
Whitlow. 1990. An ice core record of atmospheric response to anthropogenic sulphate and nitrate. Nature, 346(6284), 554-556.

Mulvaney, R. and E.W. Wolff. 1994. Spatial variability of the major chemistry of the Antarctic ice sheet. Ann. Glaciol., 20, 440-447.

Mulvaney, R., D. Wagenbach and E. Wolff. 1998. Postdepositional change in snowpack nitrate from observation of year-round near-surface snow in coastal Antarctica. 7. Geophys. Res., 103(D9), 11,021-11,031.

Narita, H. 1971. [Specific surface of deposited snow. II.] Low Temp. Sci., Ser. A, 29, 69-79. [InJapanese with English summary.]

Neftel, A., J. Beer, H. Oeschger, F. Zürcher and R.C. Finkel. 1985. Sulphate and nitrate concentrations in snow from south Greenland, 1895-1978. Nature, 314(6012), 611-613.

Röthlisberger, R., M. A. Hutterli, S. Sommer, E.W.Wolff and R. Mulvaney. 2000a. Factors controlling nitrate in ice cores: evidence from the Dome C deep ice core. 7. Geophys. Res., 105(D16), 20,565-20,572.

Röthlisberger, R. and 6 others. 2000b. Technique for continuous high-resolution analysis of trace substances in firn and ice cores. Environ. Sci. Technol., 34(2), 338-342.

Seinfeld, J. H. and S. N. Pandis. 1998. Atmospheric chemistry and physics: from air pollution to climate change. New York, John Wiley and Sons.

Steffensen, J. P. 1988. Analysis of the seasonal variation in dust, $\mathrm{Cl}^{-}, \mathrm{NO}_{3}{ }^{-}$ and $\mathrm{SO}_{4}{ }^{2-}$ in two central Greenland firn cores. Ann. Glaciol., 10, 171-177.

Steffensen, J. P., H. B. Clausen and J. M. Christensen. 1996. On the spatial variability of impurity content and stable isotopic composition in recent Summit snow. In Wolff, E.W. and R. C. Bales, eds. Chemical exchange between the atmosphere and polar snow. Berlin, etc., Springer-Verlag, 607615. (NATO ASI Series I: Global Environmental Change 43.)

Thibert, E. and F. Dominé. 1998. Thermodynamics and kinetics of the solid solution of $\mathrm{HNO}_{3}$ in ice. 7. Phys. Chem., Ser. B, 102, 4432-4439.

Wolff, E.W. 1995. Nitrate in polar ice. In Delmas, R. J., ed. Ice core studies of global biogeochemical cycles. Berlin, etc., Springer-Verlag, 195-224. (NATO ASI Series I: Global Environmental Change 30.)

Yang, Q. and 7 others. 1995. A global perspective of nitrate flux in ice cores. $\mathcal{F}$. Geophys. Res., 100(D3), 5113-5121.

Yang, Q., P. A. Mayewski, E. Linder, S. Whitlow and M. Twickler. 1996. Chemical species spatial distribution and relationship to elevation and snow accumulation rate over the Greenland ice sheet. F. Geophys. Res., $\mathbf{1 0 1}(\mathrm{D} 13), 18,629-18,637$. 